\title{
Life History Migrations of Adult Yellowstone Cutthroat Trout in the Upper Yellowstone River
}

\author{
Authors: Brian D. Ertel, Thomas E. McMahon, Todd \\ M. Koel, Robert E. Gresswell, \& Jason C. Burckhardt
}

This is an Accepted Manuscript of an article published in North American Journal of Fisheries Management on August 2017, available online:

http://www.tandfonline.com/10.1080/02755947.2017.1313793

Ertel, Brian D. , Thomas E. McMahon, Todd M. Koel, Robert E. Gresswell, and Jason C. Burckhardt. "Life History Migrations of Adult Yellowstone Cutthroat Trout in the Upper Yellowstone River." North American Journal of Fisheries Management 37, no. 4 (August 2017): 743-755. DOI: 10.1080/02755947.2017.1313793.

Made available through Montana State University's $\underline{\text { ScholarWorks }}$ scholarworks. montana.edu 


\title{
Life History Migrations of Adult Yellowstone Cutthroat Trout in the Upper Yellowstone River
}

\author{
Brian D. Ertel* \\ National Park Service, Yellowstone National Park, Fisheries and Aquatic Sciences Program, \\ Post Office Box 168, Yellowstone National Park, Wyoming 82190, USA
}

\section{Thomas E. McMahon}

Ecology Department, Fish and Wildlife Ecology and Management Program, Montana State University, Post Office Box 173460, Bozeman, Montana 59717, USA

\section{Todd M. Koel}

National Park Service, Yellowstone National Park, Fisheries and Aquatic Sciences Program, Post Office Box 168, Yellowstone National Park, Wyoming 82190, USA

\section{Robert E. Gresswell}

U.S. Geological Survey, Northern Rocky Mountain Science Center, 2327 University Way, Bozeman, Montana 59715, USA

\section{Jason C. Burckhardt}

Wyoming Game and Fish Department, 2820 State Highway 120, Cody, Wyoming 82414, USA

\begin{abstract}
Knowledge of salmonid life history types at the watershed scale is increasingly recognized as a cornerstone for effective management. In this study, we used radiotelemetry to characterize the life history movements of Yellowstone Cutthroat Trout Oncorhynchus clarkii bouvieri in the upper Yellowstone River, an extensive tributary that composes nearly half of the drainage area of Yellowstone Lake. In Yellowstone Lake, Yellowstone Cutthroat Trout have precipitously declined over the past 2 decades primarily due to predation from introduced Lake Trout Salvelinus namaycush. Radio tags were implanted in 152 Yellowstone Cutthroat Trout, and their movements monitored over 3 years. Ninety-six percent of tagged trout exhibited a lacustrine-adfluvial life history, migrating upstream a mean distance of $42.6 \mathrm{~km}$ to spawn, spending an average of $24 \mathrm{~d}$ in the Yellowstone River before returning to Yellowstone Lake. Once in the lake, complex postspawning movements were observed. Only $4 \%$ of radio-tagged trout exhibited a fluvial or fluvial-adfluvial life history. Low prevalence of fluvial and fluvialadfluvial life histories was unexpected given the large size of the upper river drainage. Study results improve understanding of life history diversity in potamodromous salmonids inhabiting relatively undisturbed watersheds and provide a baseline for monitoring
\end{abstract}

Yellowstone Cutthroat Trout response to management actions in Yellowstone Lake.

Over the past two decades, studies of salmonid migrations occurring within freshwater environments (potamodromy) have revealed a much greater degree of complexity than previously recognized (Northcote 1997; Bennett et al. 2014). Four distinctive life history migration patterns have been defined in an attempt to categorize the wide range of movements observed: (1) fluvial (spawning and seasonal movements occur within a single stream), (2) fluvial-adfluvial (rearing in large river and spawning in smaller tributary), (3) lacustrine-adfluvial (lake rearing and migration to spawn in inlet tributary), and (4) allacustrine (lake rearing and migration to spawn in outlet tributary; Varley and Gresswell 1988; Northcote 1997).

Life history patterns can be highly variable even within a single drainage system. For example, Rainbow Trout 
Oncorhynchus mykiss in the Alagnak River drainage, Alaska, display lacustrine-adfluvial, allacustrine, and fluvial life histories (Meka et al. 2003). Bull Trout Salvelinus confluentus in the Salmon River drainage, Idaho, display both fluvial and fluvial-adfluvial life histories (Hogen and Scarnecchia 2006; Watry and Scarnecchia 2008). The scale of migrations also varies widely, from $<5 \mathrm{~km}$ (Gresswell and Hendricks 2007) to $100 \mathrm{~km}$ or more (Fraley and Shepard 1989; Muhlfeld et al. 2009).

Extensive surveys of Yellowstone Lake have been conducted since the Jordan expedition of 1889 (Jordan 1891). Indeed, much of the initial description of the range of life history variation present among freshwater salmonids originated from studies of Yellowstone Cutthroat Trout $O$. clarkii bouvieri inhabiting Yellowstone Lake, Yellowstone National Park. Within Yellowstone Lake and its tributary streams, the presence of all four potamodromous life history migration patterns for salmonids were first described (Cope 1957; Bulkley 1963; Varley and Gresswell 1988). The lacustrineadfluvial migration pattern is predominant in Yellowstone Lake; the other three life histories are also present but occur at much lower frequencies. Generally, Yellowstone Cutthroat Trout in Yellowstone Lake classified as lacustrine-adfluvial migrate upstream to spawn in 68 of the lake's 124 total inlet tributaries (Gresswell and Varley 1988; Reinhart and Mattson 1990) from May to early July (Ball 1955; Gresswell et al. 1997). Spawning-sized individuals spend approximately 1-3 weeks in a stream before returning to the lake (Ball and Cope 1961). Despite Yellowstone Lakes rich and extensive research history, the upper Yellowstone River, the largest tributary to the lake, has been largely unexplored. Because of its remoteness, the life history patterns and spawning migrations of Yellowstone Cutthroat Trout in this major tributary system have not been documented. The large size and extensive tributary network of the upper Yellowstone River (Figure 1), suggest the potential for the occurrence of long distance upstream spawning migrations and for support of multiple life history types.

Characterizing the range of life history types and habitats utilized by species at the watershed scale is increasingly recognized as a cornerstone of effective conservation and management (Fausch et al. 2002; Homel et al. 2015). The objectives of our study were to determine the proportion of life history types of Yellowstone Cutthroat Trout within the extensive upper Yellowstone River drainage and the timing of their spawning migrations. We hypothesized that this large, undisturbed drainage is an important source of life history diversity in the Yellowstone Lake ecosystem. Yellowstone Cutthroat Trout in the upper Yellowstone River drainage may be an increasingly important component in the overall production of the Yellowstone Lake population given the precipitous decline in the lake population. The decline in the Yellowstone Cutthroat Trout lake population is from a combination of drought, whirling disease, and, especially, predation and competition from introduced Lake Trout S. namaycush (Ruzycki et al. 2003; Koel et al. 2006, 2015; Kaeding 2010).

\section{STUDY AREA}

The study area included the upper Yellowstone River drainage $\left(1,244 \mathrm{~km}^{2}\right)$ and Yellowstone Lake $\left(345 \mathrm{~km}^{2}\right)$ in northwestern Wyoming (Figure 1). The upper Yellowstone River drainage is the largest tributary of Yellowstone Lake, encompassing approximately $42 \%$ of the total drainage area (Gresswell et al. 1997). The main stem upper Yellowstone River flows $73 \mathrm{~km}$ from the confluence of the north $(9.2 \mathrm{~km})$ and south $(11.4 \mathrm{~km})$ forks to the Yellowstone Lake inlet. An additional $200 \mathrm{~km}$ of major and minor tributaries are accessible to migratory fish in the upper river drainage below waterfalls and cascades that act as migration barriers (Ertel 2011). Major tributaries include, Thorofare Creek (45 km), Mountain Creek $(29 \mathrm{~km})$, Atlantic Creek $(13 \mathrm{~km})$, and Trappers Creek (9 $\mathrm{km})$.

The drainage upstream from the Castle Creek confluence (Figure 1) is composed of a series of riffle-pool complexes surrounded by steep, forested slopes. Stream substrate is predominantly boulders and cobble, and river gradient is $11.6 \mathrm{~m} / \mathrm{km}$. Downstream of the Castle Creek confluence, the river flows through open meadows and has much lower gradient $(0.96 \mathrm{~m} / \mathrm{km})$. In this portion of the drainage, the river is characterized by long, shallow runs and a few large, deep pools positioned near tributary mouths; substrate is predominantly gravel, sand, and cobble. Native Yellowstone Cutthroat Trout and Longnose Dace Rhinichthys cataractae are present in the Yellowstone River along with nonnative Redside Shiners Richardsonius balteatus and Longnose Suckers Catostomus catostomus in the lower river reaches. These species, in addition to Lake Chub Couesius plumbeus and Lake Trout, occur in Yellowstone Lake (Varley and Schullery 1998).

\section{METHODS}

Radiotelemetry was used to determine spawning and postspawning movement of adult Yellowstone Cutthroat Trout over 3 years (June 2003 to August 2006). Yellowstone Cutthroat Trout in the upper Yellowstone River were implanted with radio tags: 63 in $2003(n=63), 2004(n=71)$, and $2005(n=$ $18)$. They were captured by angling $(n=144)$ and in gill nets or fyke nets $(n=8)$ set near the river mouth. During angling, two to six anglers walked stream banks from the river mouth upstream along the entire length of the main stem and major tributaries below migration barriers; all pools, runs, tributary mouths, and areas where Yellowstone Cutthroat Trout or redds were observed were angled. To maximize the likelihood of sampling all potential spawning life history types present in the upper Yellowstone River (lacustrine-adfluvial, fluvialadfluvial, and fluvial), radio tags were apportioned over space and time. Spatially, sampling occurred from the river mouth 


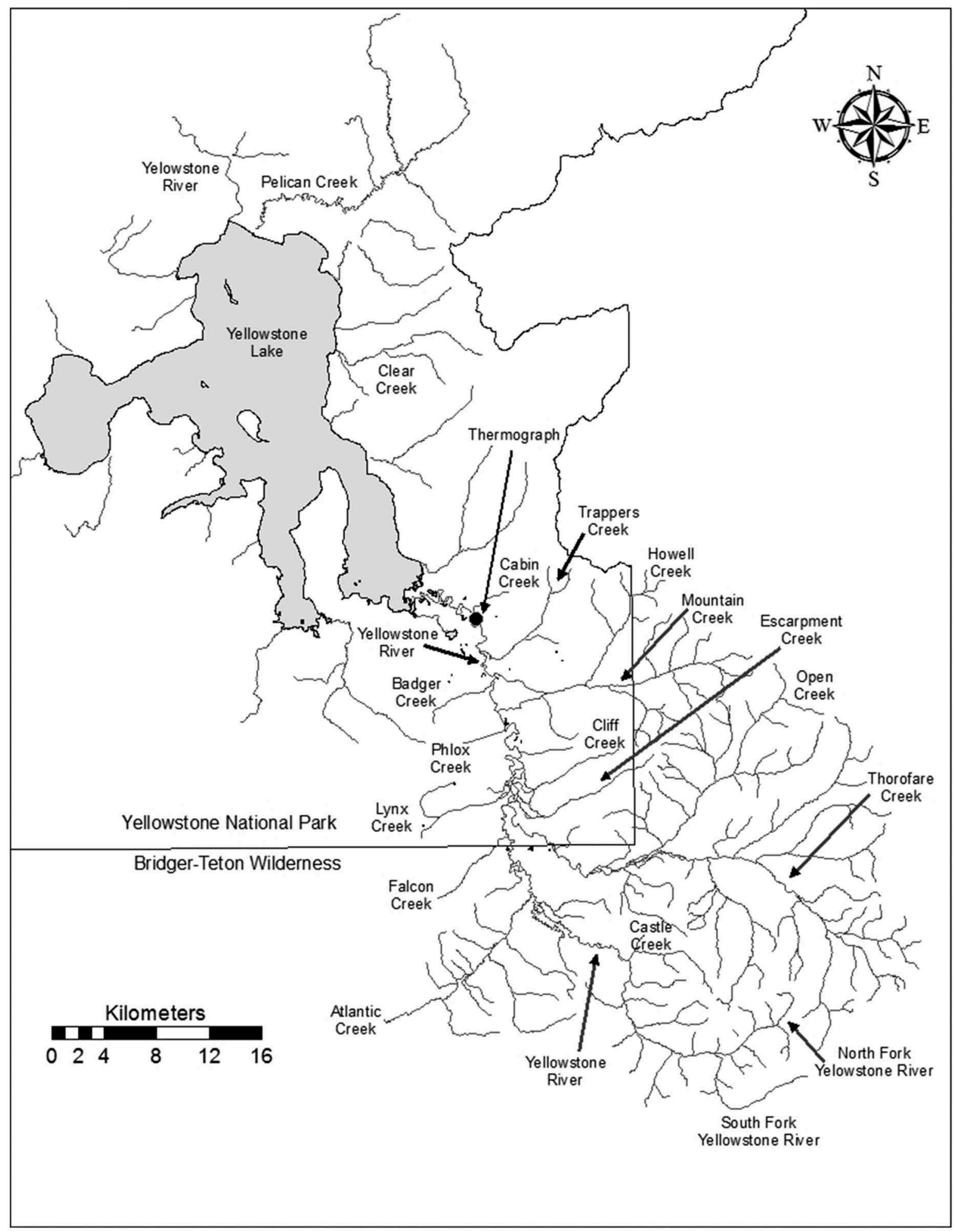

FIGURE 1. Upper Yellowstone River drainage study area from the Yellowstone River headwaters to Yellowstone Lake, including Yellowstone Lake and upper Yellowstone River tributary streams, where radio-tagged Yellowstone Cutthroat Trout were surveyed.

upstream to the confluence of the North and South Forks. Radio tags were apportioned by implanting about half in trout captured in the main-stem Yellowstone River $(n=70)$ or Yellowstone Lake $(n=8)$ by the river inlet, to target presumed 
lacustrine-adfluvial and fluvial-adfluvial life history forms. To target the fluvial or fluvial-adfluvial life history form, the other half of the radio tags were deployed in trout captured in 74 main-stem tributaries: Thorofare (50), Mountain (12), Trappers (6), and Atlantic (6) creeks. Temporally, tag implantation was divided into spawning and postspawning periods. Previous studies indicated that the lacustrine-adfluvial type in Yellowstone Lake typically migrate upstream to spawn in May and June and return to the lake by the end of July (Gresswell et al. 1997). Therefore, radio tags were implanted into Yellowstone Cutthroat Trout annually from May to July, when lacustrineadfluvial spawners were most likely to be present during their upstream spawning migrations; they were also implanted during from August to October, when lacustrine-adfluvial spawners would likely have returned to the lake and fluvial and fluvialadfluvial types would be present. The trout were anesthetized with clove oil (Prince and Powell 2000), measured for total length $(\mathrm{mm})$ and weight $(\mathrm{g})$ and implanted with 13 -g internal radio tags with external antennas using the shielded needle technique (Ross and Kleiner 1982). Only trout $>650 \mathrm{~g}$ were tagged to ensure that transmitter weight was less than recommended tag : body weight ratio of $<4 \%$ (Zale et al. 2005). Those $<650 \mathrm{~g}$ and ripe females with spilling eggs were not tagged. Sex was determined by the presence of eggs or milt or by examination of gonads during surgery. Subsequent data analysis suggested that there was no significant difference in spawn timing $\left(t_{24}=0.80, P=0.21\right)$, duration in the Yellowstone River $\left(t_{13}=0.02, P=0.50\right)$, or distance migrated $\left(t_{66}=0.07, P\right.$ $=0.47$ ) between male and female fish. Therefore, data from both sexes were combined for analysis. During implantation, trout were placed dorsally in a V-shaped operating table, and gills were irrigated with anaesthetic using a bulb syringe. The incision was closed using 2-4 monofilament sutures. Following surgery, Yellowstone Cutthroat Trout were held in live cages until equilibrium was regained and then released near their point of capture.

Radio tags were programmed with one of three duty cycles to ensure that battery life was sufficient to detect all potential movement patterns. For duty cycle $1(n=104)$, radio tags were programmed for $12 \mathrm{~h}$ on : $12 \mathrm{~h}$ off and 6 months on : 6 months off (expected battery life $=308-770 \mathrm{~d}$ ). Data collected from trout implanted with radio tags programmed with this duty cycle were used to assess frequency of repeat spawning and spawning site fidelity. Duty cycle $2(12 \mathrm{~h}$ on : $12 \mathrm{~h}$ off, expected battery life $=216-432 \mathrm{~d} ; n=22$ ) was used to assess spawning and postspawning movements and aid in the identification of overwintering locations and movements. Duty cycle 3 ( $8 \mathrm{~h}$ on : $16 \mathrm{~h}$ off, 3 months on : 9 months off, expected battery life $=763-1,908 \mathrm{~d} ; n=26$ ) was used to determine frequency of spawning events among years and spawning site fidelity.

Because of the large expanse and remoteness of the study area, aerial surveys were used to locate radio-tagged trout. A total of 45 aerial surveys were conducted from July 2003 to
July 2006. Surveys were conducted weekly during peak spawning and postspawning migration periods (May to August), biweekly in April and September, and monthly from November to March. The flight path (altitude 150-300 m above ground level) encompassed Yellowstone Lake and its shoreline, the main stem of the upper Yellowstone River, and all tributaries downstream of migration barriers (Ertel 2011). Two, 500-m sections were sampled upstream of each possible barrier. If no fish were found, the barrier location was recorded. Flight times were typically between 4 and $6 \mathrm{~h}$ depending on number of fish detected and weather conditions. Aerial surveys fish relocations were ascertained via an ATS R4500 receiver and data logger (Isanti, Minnesota), which recorded tag radio frequency, code number, date, time, signal strength, and GPS location (North American Datum 83). Multiple point locations for each Yellowstone Cutthroat Trout were recorded during a single tracking event to increase the likelihood of accurately determining fish position. Final point location for an individual Yellowstone Cutthroat Trout was estimated from the point with the strongest corresponding signal strength during each flight. If two point locations had equal signal strengths, the mid-point between the two was selected. Each final point location was then overlaid on maps of the study area using ArcGIS 9 (ArcMap version 9.3; ESRI, Redlands, California). Aerial surveys were supplemented with boat $(n=8)$ and foot $(n=5)$ surveys in September and October. Trout locations were estimated by triangulation with a handheld Yagi antenna or point location where fish were physically observed.

Accuracy and range of aerial telemetry was estimated by deploying test radio tags in Yellowstone Lake at depths ranging from surface to $4 \mathrm{~m}$. Signal strength and location were recorded during aerial surveys for comparison with the known location. Test radio tag location was unknown to the pilot and data recorder during testing. A signal strength of 80 (scale 1-136) was set as the cut-off for reliable detection. Detection distance ranged from $1 \mathrm{~km}$ for test radio tags placed near the lake surface to $500 \mathrm{~m}$ at $1 \mathrm{~m}$ deep and to $200 \mathrm{~m}$ at $3 \mathrm{~m}$ deep; radio tags were undetectable at $4 \mathrm{~m}$ deep.

Movement patterns of radio-tagged fish were classified into one of three spawning life histories. Those relocated in Yellowstone Lake after spawning or that showed distinctive downstream migrations over multiple relocations following presumed spawning were classified as lacustrine-adfluvial. Those relocated only in the main stem and that migrated into an adjoining tributary during the spawning season were classified as fluvial-adfluvial. Those relocated entirely within a single tributary or small area in the main stem and putatively spawned therein were classified as fluvial.

To estimate home range of the different life history types, individual locations were grouped by river kilometer, and migration distance was measured using ArcMap. Spawning 
migration distance was measured from the mouth of the river to the most upstream point where the individual fish was detected. Migration distances in Yellowstone Lake were measured by straight line distance from the mouth of the river inlet. Home range was estimated from the two most distant relocation points. Distribution patterns were analyzed by grouping relocations during three different seasonal periods: peak spawning (May and June), immediate postspawning migration (August) when most lacustrine-adfluvial trout were assumed to have returned to Yellowstone Lake, and the fall-winter refuge locations (September to March). Spawning date and location were estimated by the time and location of maximum upstream migration distance (Henderson et al. 2000; Downing et al. 2002). Spawning sites were identified by concentrations of the tagged fish at the upstream extent of migrations, visual observations of spawning Yellowstone Cutthroat Trout, or redds. Peak spawning date was considered the date when the most tagged fish were at the upstream extent of their spawning migration. For the lacustrine-adfluvial fish that migrated upriver to spawn and then returned to the lake, length of river residency was estimated from the date first recorded in the river to the date of river exit. River exit date was considered the median date between the last relocation date in the Yellowstone River and the date of relocation in Yellowstone Lake.

Timing of movement in relation to water temperature was estimated from thermographs deployed at two main stem locations (below Cabin Creek and Falcon Creek confluences) and near the mouths of five tributary streams (Cabin, Trappers, Mountain, Phlox, and Thorofare creeks). Because no significant difference was detected in the mean daily temperatures from the different locations (analysis of variance, ANOVA, $p=0.43$ ), only temperatures recorded at the lowermost main stem site (Cabin Creek, Figure 1) were used for analysis.

\section{RESULTS}

Mean total length of Yellowstone Cutthroat Trout implanted with radio tags was $460 \mathrm{~mm}$ (range, 400-544 mm). Scale analysis indicated implanted fish ranged from ages 4 to 7 years (Ertel 2011). Of the 152 Yellowstone Cutthroat Trout we radio-tagged, 95 were used for detailed analysis of movement, 39 were not relocated after tagging, 17 died or expelled their tag as indicated by presence of mortality signal, and 1 was tagged at the river mouth and never entered the upper river. Relocations used for analysis averaged 4.7 relocations per fish (range, 1-29) during the 3 years of tracking flights. Eight of the 17 radio tags emitting a mortality signal were recovered in white pelican Pelecanus erythrorhynchos and double-crested cormorant Phalacrocorax auritus rookeries on Molly Islands in Yellowstone Lake, three were found below bald eagle Haliaeetus leucocephalus perch sites, and one tag was recovered from a bear Ursus sp. scat near the Mountain Creek confluence.

Of the 95 Yellowstone Cutthroat Trout with relocations used for analysis, 91 (96\%) exhibited the lacustrine-adfluvial life history, of which 60 were relocated in Yellowstone Lake. The remaining 31 showed a distinctive and extensive downstream migration pattern after spawning in the upper Yellowstone River, indicative of a postspawning return to the lake. In 2004 and 2005, the ostensible upstream spawning migration of previously radio-tagged fish into the upper river occurred from May 24 to July 20; median entry date was June 1 in 2004 and June 13 in 2005. In 2005 the number of upstream migrants present in the river increased sharply from June 1 to June 15 , when mean daily water temperatures increased above $6^{\circ} \mathrm{C}$ (Figure 2). Estimated peak spawning date was July 6 in 2004 and June 13 in 2005 at a water temperature range of $8-10^{\circ} \mathrm{C}$. Lacustrineadfluvial Yellowstone Cutthroat Trout spent an average of $24 \mathrm{~d}$ (range, 7-82 d) in the river network before returning to Yellowstone Lake (median exit date July 10 in both years). Extended river residency after August 1 was rare (Figures 2, $3)$. Only 11 of $91(12 \%)$ fish that later migrated into Yellowstone Lake were found in the upper river after August 1, and only two remained in the river after September 1.

Lacustrine-adfluvial Yellowstone Cutthroat Trout migrated over long distances to spawn in the main-stem and tributary locations, traveling a mean distance of 42.7 $\mathrm{km}$ (range, 3.2-65.9 km) upstream from the mouth (Figure 3). Eleven distinct spawning areas were broadly spread within the upper river main stem and in the lower reaches of three tributaries (Castle, Mountain, Thorofare creeks). Spawning was concentrated in areas characterized by abundant deposits of gravel (2-64 mm diameter) spawning substrate and typically occurred near tributary con-

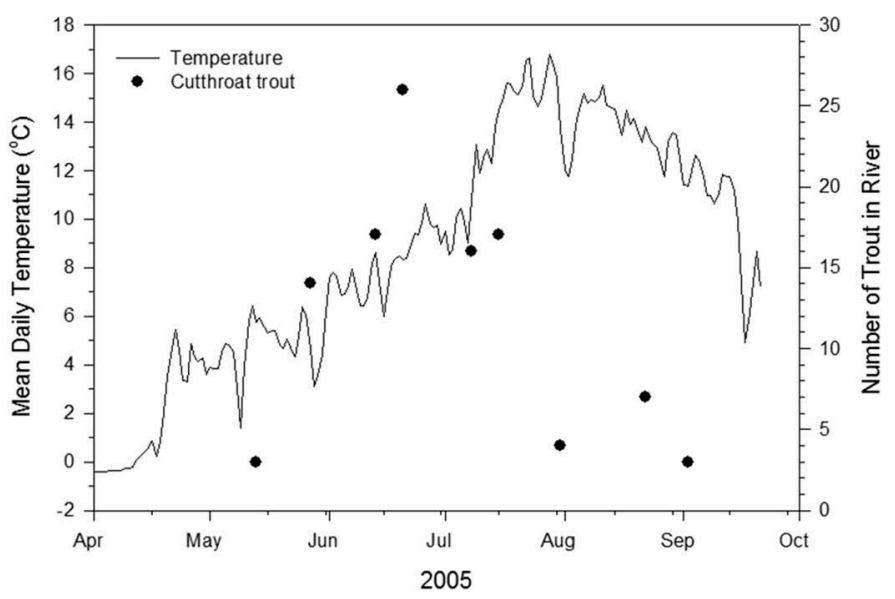

FIGURE 2. Number of radio-tagged Yellowstone Cutthroat Trout located in the upper Yellowstone River in relation to mean daily water temperature of the Lower Yellowstone River near the lake inlet, 2005. 

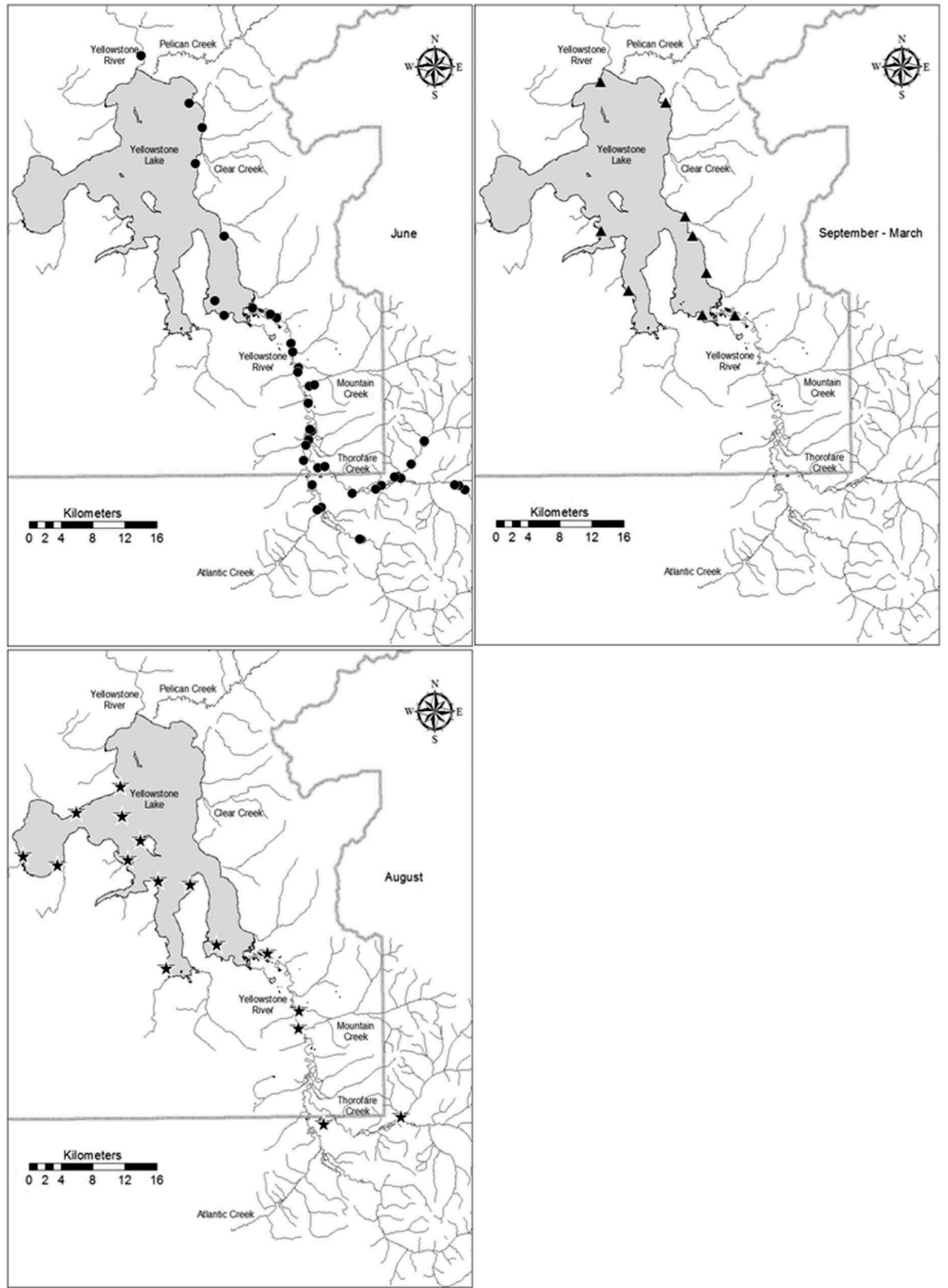

FIGURE 3. Locations of radio-tagged Yellowstone Cutthroat Trout during the peak spawning period (June), immediately postspawning (August), and fallwinter period (September-March). 
fluences. Spawning was infrequently observed in the lower main stem; just 3 of 11 spawning concentrations were located downstream of the Cliff Creek confluence (Figure 4). The highest concentrations of radio-tagged fish ( $30 \%$ of total recorded) were found at the upstream extent of their migrations at river kilometer (rkm) 35 and 41 near the Yellowstone River confluences with Cliff and Thorofare creeks. Five of 11 spawning concentrations were located upstream of the Yellowstone National Park boundary.

Patterns of repeat homing behavior (individuals returning to the same tributary in multiple years; McCleave 1967) were based on relocation records from 28 fish that made more than one upstream spawning migration over 2-3 years during the May-July spawning period (Table 1). Of these individuals 26 (93\%) exhibited upstream spawning migrations in at least 2 consecutive years and $2(7 \%)$ showed an alternate year spawning pattern. Repeat spawners were located a mean distance of $3.7 \mathrm{~km}$ (range, $0-52 \mathrm{~km}$ ) from their previous spawning location, $55 \%$ being relocated within $1 \mathrm{~km}$ and $78 \%$ within $3 \mathrm{~km}$. Seven tagged fish returned to spawn in all three seasons, all were males. Three of seven were found in the same location each season, and five were found within $3 \mathrm{~km}$ of their original spawning location. There was no evidence of straying among repeat spawners because no radio-tagged Yellowstone

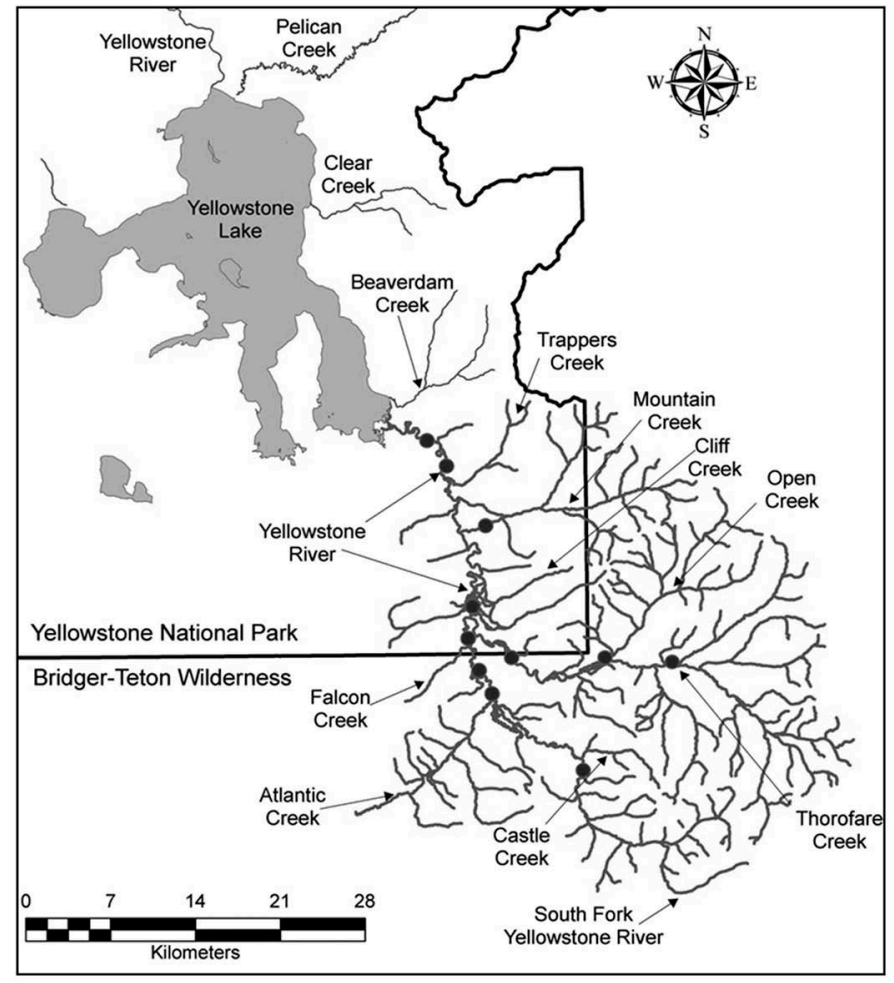

FIGURE 4. Locations of spawning concentrations of radio-tagged Yellowstone Cutthroat Trout, upper Yellowstone River basin, 2005-2006. Spawning grounds were identified by the concentrations of Yellowstone Cutthroat Trout at the upstream extent of their spawning migration or by visual observations of spawning trout or redds.
TABLE 1. Spawning year and locations (i.e., distance from Yellowstone Lake) of Yellowstone Cutthroat Trout repeat spawners in the upper Yellowstone River basin, Wyoming, 2003-2006, where MC = Mountain Creek, THC $=$ Thorofare Creek, TRP $=$ Trappers Creek, YSR $=$ Yellowstone River, $\mathrm{L}-\mathrm{A}=$ lacustrine-adfluvial, $\mathrm{F}-\mathrm{A}=$ fluvial-adfluvial, and $\mathrm{F}=$ fluvial.

\begin{tabular}{|c|c|c|c|c|c|c|}
\hline \multirow[b]{2}{*}{$\begin{array}{l}\text { Fish } \\
\text { code }\end{array}$} & \multirow[b]{2}{*}{ Sex } & \multirow[b]{2}{*}{ Stream } & \multicolumn{3}{|c|}{$\begin{array}{c}\text { Distance from the } \\
\text { lake }(\mathrm{km})\end{array}$} & \multirow{2}{*}{$\begin{array}{l}\text { Life } \\
\text { history } \\
\text { type }\end{array}$} \\
\hline & & & $\begin{array}{c}\text { Year } \\
1\end{array}$ & $\begin{array}{l}\text { Year } \\
2\end{array}$ & $\begin{array}{c}\text { Year } \\
3\end{array}$ & \\
\hline $267-20$ & Male & $\mathrm{MC}$ & 22.2 & & 22.6 & $\mathrm{~L}-\mathrm{A}$ \\
\hline $317-22$ & Male & YSR & 35.2 & 37.1 & 35.2 & $\mathrm{~L}-\mathrm{A}$ \\
\hline $368-20$ & Male & YSR & 35.0 & 35.0 & & $\mathrm{~L}-\mathrm{A}$ \\
\hline $418-20$ & Male & YSR & 35.8 & 35.8 & & $\mathrm{~L}-\mathrm{A}$ \\
\hline $418-21$ & Female & THC & 60.7 & 60.7 & & $\mathrm{~L}-\mathrm{A}$ \\
\hline $466-20$ & Unknown & THC & & 8.6 & 8.4 & $\mathrm{~F}-\mathrm{A}$ \\
\hline $466-21$ & Unknown & YSR & 32.3 & 32.3 & & $\mathrm{~L}-\mathrm{A}$ \\
\hline $516-21$ & Male & YSR & & 60.1 & 60.1 & $\mathrm{~L}-\mathrm{A}$ \\
\hline $566-17$ & Male & YSR & 61.1 & 60.6 & 58.3 & $\mathrm{~L}-\mathrm{A}$ \\
\hline $566-24$ & Male & $\mathrm{MC}$ & 21.4 & & 22.6 & $\mathrm{~L}-\mathrm{A}$ \\
\hline $617-16$ & Female & THC & 63.8 & 63.8 & & $\mathrm{~L}-\mathrm{A}$ \\
\hline $\begin{array}{l}617- \\
17 \mathrm{~B}\end{array}$ & Female & THC & 16.5 & 16.5 & & $\mathrm{~L}-\mathrm{A}$ \\
\hline $617-18$ & Female & YSR & 61.6 & 61.6 & & $\mathrm{~L}-\mathrm{A}$ \\
\hline $617-19$ & Female & YSR & 65.1 & 13.1 & 19.8 & $\mathrm{~L}-\mathrm{A}$ \\
\hline $668-16$ & Male & THC & 52.8 & 61.1 & & $\mathrm{~L}-\mathrm{A}$ \\
\hline $668-17$ & Female & THC & 61.7 & 52.8 & & $\mathrm{~L}-\mathrm{A}$ \\
\hline $668-19$ & Male & THC & 52.8 & 48.1 & & $\mathrm{~L}-\mathrm{A}$ \\
\hline $668-21$ & Male & YSR & 39.9 & 22.2 & & $\mathrm{~L}-\mathrm{A}$ \\
\hline 716-16 & Female & THC & 52.8 & 52.8 & 52.8 & $\mathrm{~L}-\mathrm{A}$ \\
\hline $742-19$ & Male & THC & 43.4 & 46.5 & & $\mathrm{~L}-\mathrm{A}$ \\
\hline $742-21$ & Male & THC & 43.1 & 54.1 & & $\mathrm{~L}-\mathrm{A}$ \\
\hline 766-18 & Male & YSR & 60.7 & 60.7 & & $\mathrm{~L}-\mathrm{A}$ \\
\hline $766-21$ & Male & THC & 40.3 & 43.1 & & $\mathrm{~L}-\mathrm{A}$ \\
\hline 792-19 & Male & THC & 53.4 & 54.2 & & $\mathrm{~L}-\mathrm{A}$ \\
\hline $817-16$ & Female & THC & 52.8 & 55.6 & & $\mathrm{~L}-\mathrm{A}$ \\
\hline $817-23$ & Unknown & THC & 41.1 & 41.1 & 41.1 & $\mathrm{~L}-\mathrm{A}$ \\
\hline $923-15$ & Female & YSR & 17.9 & 17.9 & 17.9 & $\mathrm{~L}-\mathrm{A}$ \\
\hline $967-15$ & Female & THC & 53.0 & 53.8 & & $\mathrm{~L}-\mathrm{A}$ \\
\hline
\end{tabular}

Cutthroat Trout were found in other tributaries to the lake during the spawning period.

During the spawning period (May-July), few radiotagged fish were found in Yellowstone Lake (Figure 3). Lacustrine-adfluvial Yellowstone Cutthroat Trout made extensive postspawning movements in Yellowstone Lake. For example, by August immediately following the spawning period, radio-tagged fish were relocated throughout the lake, and only $9 \%$, ( 1 of 11 relocations) remained in the Southeast Arm near the upper Yellowstone River inlet (Figure 3). Another fish classified as lacustrine-adfluvial entered the Yellowstone River at the outlet of Yellowstone Lake, on the north end of Yellowstone Lake. This 
movement occurred on only one occasion (July 15, 2005) before the fish returned to Yellowstone Lake. Although relatively few fish were relocated during the fall-winter period, relocations continued to be widespread in the lake (Figure 3).

Overall movement range was difficult to quantify for most lacustrine-adfluvial Yellowstone Cutthroat Trout because only intermittent tag relocations in Yellowstone Lake were obtained. However, we estimated overall migration distance by summing mean upriver migration distance $(42.7 \mathrm{~km}$; range, $3.2-65.9 \mathrm{~km})$ with the mean length of the lake movements $(17.5 \mathrm{~km}$; range, $4.8-54.3 \mathrm{~km})$, yielding an overall estimated mean movement range of $60.2 \mathrm{~km}$. For example, soon after initial tagging in June of 2004, one fish (617-18) moved from its spawning location downstream into Yellowstone Lake, and during July moved north along the Southeast Arm of the lake (Figure 5). It was relocated again in mid-June of 2005, when it was detected in the upper Yellowstone River near Badger Creek and in early July returned to the same spawning location as the previous year. It was not relocated again until June 2006 when it was detected in Yellowstone Lake, overall illustrating repeat spawning and extensive seasonal movements upriver and within the lake.

Three radio-tagged Yellowstone Cutthroat Trout (3\%) displayed a movement pattern characteristic of a fluvial life history, and one (1\%) exhibited a fluvial-adfluvial life history movement pattern. Mean movement distance for fluvial and fluvial-adfluvial Yellowstone Cutthroat Trout was $13.9 \mathrm{~km}$ (range, 5-33 km). Fluvial fish remained in a relatively restricted range during all relocations, and no distinct migration patterns could be discerned. For example, trout 466-23 was relocated 24 times (and visually observed several times) from July 2003 to August 2005; all relocations occurred within a 7-km stretch in the main-stem Yellowstone River between Atlantic and Lynx creeks. This fish was classified as fluvial because it was only relocated in the main-stem Yellowstone River. Furthermore, this individual displayed no distinct downstream migration pattern, and was never detected in Yellowstone Lake. Two other fish displayed similar movement patterns.

Only one Yellowstone Cutthroat Trout exhibited a fluvial-adfluvial life history, characterized by relocations primarily in the main stem and distinctive migrations into a tributary stream during the spawning season. Trout 466-20 was relocated 23 times during a 2-year period (June 2003 to July 2005). Most relocations were made in the mainstem Yellowstone River, but migrations downstream to and hence upstream in Thorofare Creek to a spawning location in that tributary were observed in both June 2004 and June 2005 with return to original location shortly thereafter. All movements from this fish occurred within a $10-\mathrm{km}$ home range. No fish classified as fluvial or fluvial-adfluvial were relocated in the lower reaches of the main stem.

\section{DISCUSSION}

Yellowstone Lake is an important but now threatened stronghold for Yellowstone Cutthroat Trout (Gresswell et al. 1994; Koel et al. 2005). Our study provided insight into the life history and movement patterns of this rare subspecies in the previously unstudied upper Yellowstone River, a large and extensive drainage that comprises nearly half of the drainage area of Yellowstone Lake. Assessment of spawning location and life history movement patterns of Yellowstone Cutthroat Trout revealed the presence of three life history types in the upper river, although the proportions of the three types occurred at substantially different levels. The complex, extensive spawning and postspawning movements we observed in the upper river and Yellowstone Lake were heretofore undescribed.

The high proportion of the lacustrine-adfluvial life history (96\% of tagged fish) corresponds with previous studies in other tributaries to Yellowstone Lake that also documented the predominance of this life history (Ball and Cope 1961; Varley and Gresswell 1988; Gresswell et al. 1994). The dominance of the lacustrine-adfluvial life history has been documented in other potamodromous salmonids, such as Bull Trout, where large lakes afford rapid growth opportunities (Fraley and Shepard 1989). Yellowstone Cutthroat Trout in Yellowstone Lake exhibit high growth rates, and mean total length of spawning adults is about $400 \mathrm{~mm}$ at ages 4-5 (Ertel 2011; Kaeding and Koel 2011). In contrast, nonmigratory Yellowstone Cutthroat Trout populations inhabiting small, high-elevation streams grow at much slower rates, attaining a mean total length of $261 \mathrm{~mm}$ at age 4 (Kruse et al. 1997). Upstream spawning migrations of the extent we observed in Yellowstone Cutthroat Trout categorized as lacustrine-adfluvial have not been previously documented in the Yellowstone Lake drainage. Rather, most spawning has been observed within the lower $2 \mathrm{~km}$ of the numerous, relatively short $(<10$ $\mathrm{km}$ ) inlet tributaries (Cope 1957; Gresswell et al. 1997). The long distance upstream spawning migrations we observed (mean, $42.7 \mathrm{~km}$, maximum $65.9 \mathrm{~km}$ ), however, are common in other populations of Cutthroat Trout (Schrank and Rahel 2004; Muhlfeld et al. 2009; Homel et al. 2015) and in other potamodromous salmonids, including Bull Trout (Fraley and Shepard 1989; DuPont et al. 2007), where movement is unimpeded by barriers and allows access to seasonally variable and disparate habitats (Schrank and Rahel 2004; Colyer et al. 2005).

The low prevalence of fluvial and fluvial-adfluvial types in the upper river drainage was unexpected given (1) the size of the main stem (73 km long; mean wetted width, 40.7 $\mathrm{m}$; Ertel 2011), (2) the presence of numerous tributaries including two large tributaries (Thorofare and Mountain creeks) $>20 \mathrm{~km}$ long, and (3) summer water temperatures $\left(13-16^{\circ} \mathrm{C}\right.$; Figure 2) within the optimum for growth of Cutthroat Trout (Bear et al. 2007). The upper Yellowstone River is similar to the size of other river systems wherein 


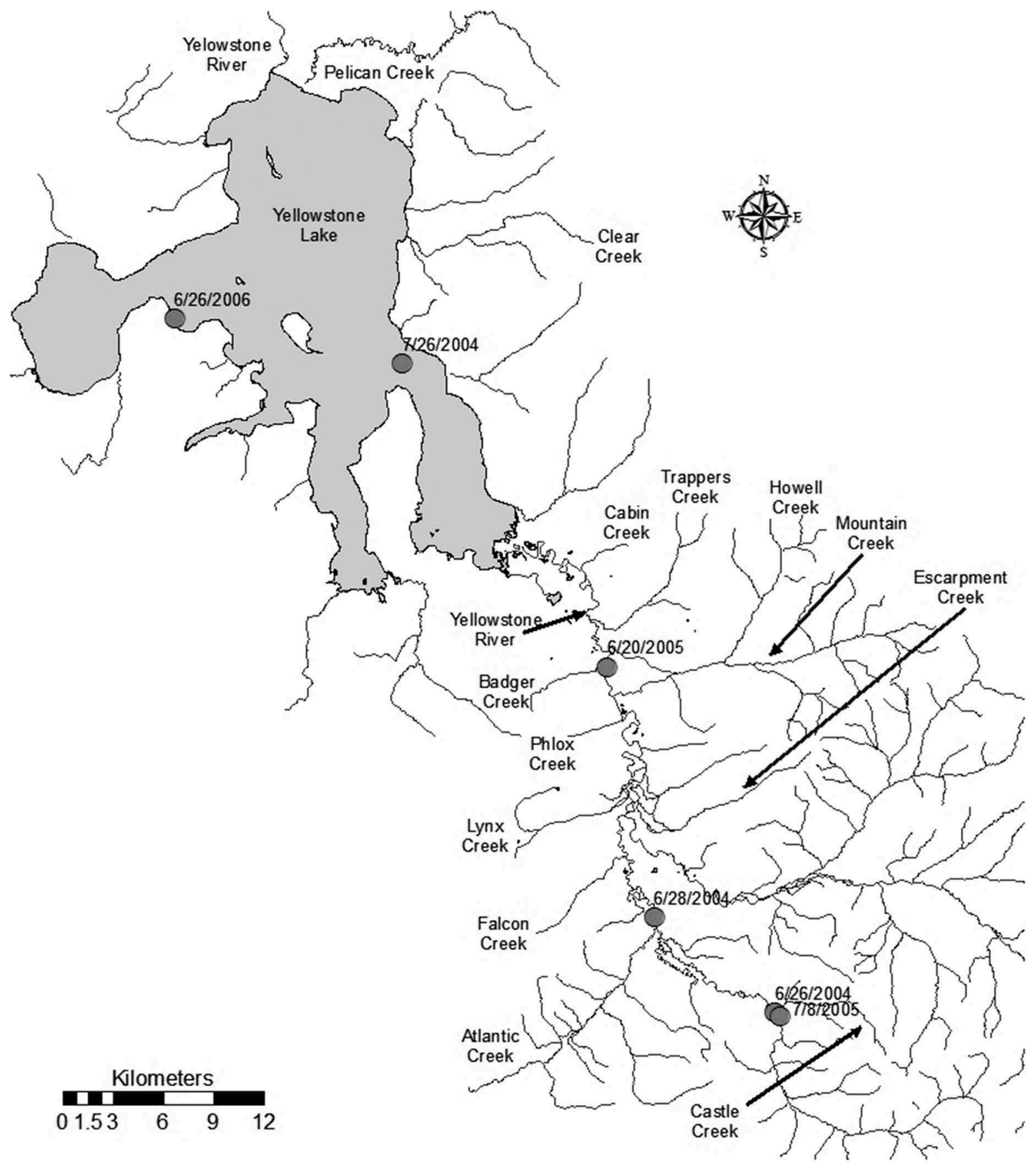

FIGURE 5. Locations by date of a Yellowstone Cutthroat Trout (tag number 617-18) in the upper Yellowstone River basin that exhibited a lacustrine-adfluvial life history. This individual returned to the lake from the river each summer following spawning.

the fluvial-adfluvial life history is common in Yellowstone Cutthroat Trout, such as the Snake River in Idaho (Henderson et al. 2000), Yellowstone River downstream of Yellowstone National Park (Byorth 1990; Derito et al. 2010), and in the closely-related Finespotted Cutthroat Trout O. clarkii behnkei (Homel et al. 2015) in the Snake River. In these systems, riverine Cutthroat Trout are common in the main stem year-round and migrate to spawn in tributaries and in main-stem side channels and the main stem itself. In our study, we also found spawning in the main stem and the lower reaches of tributaries, but a high proportion of Yellowstone Cutthroat Trout returned to Yellowstone Lake soon after spawning, resulting in very few being present in the upper river main stem after July. 
Cutthroat Trout exhibiting the fluvial life history are typically common in smaller tributaries, where spawning and rearing occur in a relatively restricted home range throughout their life cycle (Thurow et al. 1988; Gresswell and Hendricks 2007). Only three Yellowstone Cutthroat Trout (3\%) exhibited a fluvial life history in our study, and these appeared to spawn and rear in a relatively restricted home range of approximately $14 \mathrm{~km}$ in the main stem Yellowstone River. No radio-tagged fish were relocated exclusively in tributaries, and only one (1\%) exhibited a characteristic fluvial-adfluvial life history, whose relocations occurred primarily in the main stem, except during a likely spawning migration to a small tributary. Kaeding and Boltz (2001) found a similar low incidence of fluvial and fluvial-adfluvial types in the Yellowstone River outlet; $89 \%$ of their radio-tagged Yellowstone Cutthroat Trout were classified as allacustrine (outlet spawning, lake rearing), $11 \%$ categorized as fluvial, and none were fluvial-adfluvial.

It is unclear why so few Yellowstone Cutthroat Trout exhibited a fluvial or fluvial-adfluvial life history in the upper Yellowstone River. One possible explanation is that sampling bias caused the occurrence of these life histories to be underestimated. To ensure long transmitter life, we purposely used large radio tags with long battery life and, as a result, all tagged fish were $>650 \mathrm{~g}$ to maintain desired tag : body weight ratios. Fluvial and fluvial-adfluvial Yellowstone Cutthroat Trout tend to be smaller because of reduced growth rates in rivers versus lakes, so they typically mature at sizes as small as $250 \mathrm{~mm}$ (Thurow et al. 1988; Kruse et al. 1997). Therefore, lacustrine-adfluvial types may have been preferentially targeted with our radio-tagging procedures. However, only seven fish weighing $<650 \mathrm{~g}$ were sampled during tagging operations, and of these, only three weighed $<600$ g. Also, extensive electrofishing and underwater visual sampling of the main stem and seven tributaries of the upper river in September 2006, after the majority of lacustrine-adfluvial trout had returned to the lake, yielded very few fluvial and fluvial-adfluvialsized Yellowstone Cutthroat Trout (Ertel 2011). This finding provides support for the results of our radio-tagging study. Moreover, overall density of Yellowstone Cutthroat Trout, regardless of size, in surveys of the upper Yellowstone River drainage was low $(1.4 / 100 \mathrm{~m})$. In other interconnected river and lake systems, greater prevalence of the fluvial and fluvial-adfluvial is associated with high food availability in the riverine environment (e.g., Meka et al. 2003). Life history is a product of trade-offs between growth and survival (Warren and Liss 1980; Northcote 1992; Nelson et al. 2002). We hypothesize that the higher growth and survival opportunities afforded in Yellowstone Lake probably account for the predominance of the lacustrine-adfluvial type among Yellowstone Cutthroat Trout in this system. However, if the high predation rates on Yellowstone Cutthroat Trout by Lake Trout in Yellowstone Lake persist (Koel et al. 2005), the current life history composition may shift to a greater proportion of fluvial and fluvial-adfluvial types (Morita et al. 2000; Nelson et al. 2002; Gresswell 2011).

Spawning of potamodromous salmonids may take several months to complete the migration cycle (Fraley and Shepard 1989; Watry and Scarnecchia 2008). However, our results corroborate previous work with Yellowstone Cutthroat Trout in the many, short spawning streams to Yellowstone Lake tributaries; those fish display relatively rapid spawning migrations, duration of stream occupancy being only 6-25 d (Benson 1960; Gresswell et al. 1997). The lacustrineadfluvial type in our study also underwent relatively rapid upstream and downstream movements between the lake and the upper Yellowstone River, but migration distances were considerable, covering a mean roundtrip distance of $85 \mathrm{~km}$ in about 3 weeks. Our observations on the timing of spawning migrations also corroborate previous studies of Yellowstone Cutthroat Trout reporting movement into spawning areas as water temperatures rise and discharge decreases following the spring runoff peak, peak spawning occurring shortly thereafter, typically near mid to late June (Gresswell et al. 1997; Derito et al. 2010; Homel et al. 2015).

Yellowstone Cutthroat Trout from the upper Yellowstone River displayed a high level of consecutiveyear spawning migrations and spawning site fidelity. Indeed, we found that $31 \%$ of radio-tagged fish spawned more than once. This is a greater proportion of repeat spawners than has been reported for other Yellowstone Lake tributaries (23\%; Gresswell 2011) and from other Yellowstone Cutthroat Trout populations (15\% in Idaho streams; Thurow et al. 1988). Of the return spawners, $93 \%$ spawned in consecutive years. The prevalence of consecutive-year spawners we observed is much greater than previously reported for Yellowstone Lake spawning populations (Bulkley 1961) and for other potamodromous salmonids (Bull Trout) where alternate-year spawning is more prevalent (e.g., Watry and Scarnecchia 2008). There is evidence, however, that these demographic characteristics are sensitive to environmental conditions and can change through time in the same population (Gresswell 2011). In Yellowstone Lake, during the 1950s and 1960s, when angling harvest was much greater, it was estimated that up to $99 \%$ of the Yellowstone Cutthroat Trout spawning population was composed of first-time spawners (Ball and Cope 1961), and the few repeat spawners in the system were most often consecutive-year spawners (Bulkley 1961). As regulations became more restrictive and harvest declined, alternative-year spawning became more prominent (Jones et al. 1985), indicating that the availability of food resources may influence the frequency of spawning as population density increases. With the 
recent reduction in Yellowstone Cutthroat Trout abundance in Yellowstone Lake, migration patterns may be expected to resemble earlier conditions when angler harvest was greater and the percentage of consecutive-year spawners was similar to our observations.

One short coming of our study was the inability to determine movement patterns for $38 \%(n=57)$ of tagged fish; however, tag loss can be high in telemetry studies (Sanderson and Hubert 2009). For example, DeRito et al. (2010) reported that $55 \%$ of their radio-tagged trout in the Yellowstone River north of Yellowstone National Park either perished or expelled radio tags during spawning. Radio tags expelled or lost because of mortality in the upper Yellowstone River during our study would have likely been washed downstream into deep pools where detection was difficult. Because lacustrine-adfluvial Yellowstone Cutthroat Trout in the upper Yellowstone River return to the lake soon after spawning, it is possible that some individuals resided at depths greater than the detection limits of our receivers. Our inability to detect radio tags at depths $>4 \mathrm{~m}$ biased our study against relocating tagged fish in the lake. However, of the 95 tagged fish we classified, 60 were detected in Yellowstone Lake, and an additional 31 were classified as lacustrine-adfluvial, based on their movement patterns downstream towards the lake.

Yellowstone Cutthroat Trout that spawned in the upper Yellowstone River exhibited extensive postspawning movements, dispersing widely in Yellowstone Lake soon after re-entry. Previous studies in Yellowstone Lake inferred that Yellowstone Cutthroat Trout tend to reside within subbasins nearest spawning tributaries (Liebelt 1968; Gresswell et al. 1997). However, we found relocations to be widespread throughout the lake and individuals probably traversed much of the lake during the nonspawning months. The infrequent relocation events and low levels of detection of fish at depth, however, prevented more detailed delineation of movement patterns. Lake Trout movement in Yellowstone Lake is currently being monitored with an acoustic telemetry array to assess threedimensional movement and habitat use (R. E. Gresswell, unpublished data), and using this technology for monitoring movement of Yellowstone Cutthroat Trout in the lake would provide more definitive insights into seasonal movements of native trout and degree of spatial overlap with invasive Lake Trout.

Our study was conducted during a period of sharp decline in the abundance of Yellowstone Cutthroat Trout in Yellowstone Lake. Their abundance, estimated to be $90 \%$ below historical averages (Koel et al. 2005), is associated with the expanding population of introduced, predacious Lake Trout. The effect of predation on Yellowstone Cutthroat Trout abundance in the upper river is unknown because historical information does not exist. We were not able to determine the effects of predation on the life history and spawning of the upper-river
Yellowstone Cutthroat Trout. However, the low numbers of the fluvial and fluvial-adfluvial types we identified during this study further underscores the importance of the Yellowstone Lake metapopulation to this subspecies.

The large and extensive migrations we observed emphasize the importance of maintaining intact migratory pathways for maintenance of life history diversity in Yellowstone Cutthroat Trout and other potamodromous salmonids. Much of the life history diversity of potamodromous salmonids has been lost due to habitat fragmentation and nonnative species invasion (e.g., Nelson et al. 2002). For example, Yellowstone Cutthroat Trout have been extirpated from $70 \%$ of their historical range in Wyoming and are now generally restricted to spatially isolated headwater streams (Kruse et al. 2000). Restoration of lost life history diversity is increasingly recognized as an important conservation component for enhancing population resiliency (Moore et al. 2010; Carlson and Satterhwaite 2011). Knowledge of life history diversity in potamodromous salmonids occurring in relatively intact drainages lacking migration barriers and associated habitat fragmentation is important because so few examples of life history diversity exist for relatively undisturbed systems (Homel et al. 2015). Accordingly, knowledge of life history potential among species is vital for providing the template for restoring the lost life history diversity in native fishes.

\section{ACKNOWLEDGMENTS}

We thank Carter Kruse, Nicole Legere, Pat Bigelow, Steve Yekel, Bonnie Griffis, and many others for providing assistance with field work, logistics, and insight into conducting this project. We thank Andriana Puchany, Colleen Detjens, and two anonymous reviewers for providing insightful edits that improved our manuscript greatly. We would also like to thank the National Fish and Wildlife Foundation, Jackson Hole One Fly, and the Yellowstone Park Foundation for providing funding. We are indebted to the National Park Service and Wyoming Game and Fish Department for providing additional funding and personnel. Any use of trade, firm, or product names is strictly for descriptive purposes and is not an endorsement by the U.S. Government.

\section{REFERENCES}

Ball, O. P. 1955. Some aspects of homing in Cutthroat Trout. Utah Academy Proceedings 32:75-80.

Ball, O. P., and O. B. Cope. 1961. Mortality studies on Cutthroat Trout in Yellowstone Lake. U.S. Fish and Wildlife Service Research Report 55.

Bear, E. A., T. E. McMahon, and A. V. Zale. 2007. Comparative thermal requirements of westslope Cutthroat Trout and Rainbow Trout: implications to species interactions and development of thermal protection standards. Transactions of the American Fisheries Society 136:11131121.

Bennett, S., R. Al-Chokhachy, B. B. Roper, and P. Budy. 2014. Annual variation of spawning Cutthroat Trout in a small western USA stream: a 
case study with implications for the conservation of potamodromous trout life history diversity. North American Journal of Fisheries Management 34:1033-1046.

Benson, N. G. 1960. Factors influencing production of immature Cutthroat Trout in Arnica Creek, Yellowstone Park. Transactions of the American Fisheries Society 89:168-175.

Bulkley, R. V. 1961. Fluctuations in age composition in growth rate of Cutthroat Trout in Yellowstone Lake. U.S. Fish and Wildlife Service Research Report 54

Bulkley, R. V. 1963. Natural variation in spotting, hyoid teeth counts, and coloration of Yellowstone Cutthroat Trout. U.S. Fish and Wildlife Service Special Science Report Fish 460.

Byorth, P. A. 1990. An evaluation of Yellowstone Cutthroat Trout production in three tributaries of the Yellowstone River, Montana. Master's thesis. Montana State University, Bozeman.

Carlson, S. M., and W. H. Satterthwaite. 2011. Weakened portfolio effect in a collapsed salmon population complex. Canadian Journal of Fisheries and Aquatic Sciences 68:1579-1589.

Colyer, W. T., J. L. Kershner, and R. H. Hilderbrand. 2005. Movements of fluvial Bonneville Cutthroat Trout in the Thomas Fork of the Bear River, Idaho-Wyoming. North American Journal of Fisheries Management 25:954-963.

Cope, O. B. 1957. Races of Cutthroat Trout in Yellowstone Lake. U.S. Fish and Wildlife Service Special Science Report Fish 208:74-84.

De Rito, J. N., A. V. Zale, and B. B. Shepard. 2010. Temporal reproductive separation of fluvial Yellowstone Cutthroat Trout from Rainbow Trout and hybrids in the Yellowstone River. North American Journal of Fisheries Management 30:866-886.

Downing, D. C., T. E. McMahon, B. L. Kerans, and E. R. Vincent. 2002. Relation of spawning and rearing life history of Rainbow Trout and susceptibility to Myxobolus cerebralis infection in the Madison River, Montana. Journal of Aquatic Animal Health 14:191-203.

DuPont, J. M., R. S. Brown, and D. R. Geist. 2007. Unique allacustrine migration patterns of a bull trout population in the Pend Oreille River drainage, Idaho. North American Journal of Fisheries Management 27:1268-1275.

Ertel, B. D. 2011. Distribution, movements, and life-history characteristics of Yellowstone Cutthroat Trout Oncorhynchus clarkii bouvieri in the upper Yellowstone River drainage. Master's thesis. Montana State University, Bozeman.

Fausch, K. D., C. E. Torgersen, C. V. Baxter, and H. W. Li. 2002. Landscapes to riverscapes: bridging the gap between research and conservation of stream fishes. BioScience 52:483-498.

Fraley, J. J., and B. B. Shepard. 1989. Life history, ecology and population status of migratory Bull Trout (Salvelinus confluentus) in the Flathead Lake and River system, Montana. Northwest Science 63:133-142.

Gresswell, R. E. 2011. Biology, status, and management of the Yellowstone Cutthroat Trout. North American Journal of Fisheries Management 31:782-812.

Gresswell, R. E., and S. R. Hendricks. 2007. Population-scale movement of coastal Cutthroat Trout in a naturally isolated stream network. Transactions of the American Fisheries Society 136:238-253.

Gresswell, R. E., W. J. Liss, and G. L. Larson. 1994. Life-history organization of Yellowstone Cutthroat Trout (Oncorhynchus clarki bouvieri) in Yellowstone Lake. Canadian Journal of Fisheries and Aquatic Sciences 51(Supplement 1):298-309.

Gresswell, R. E., W. J. Liss, G. L. Larson, and P. J. Bartlein. 1997. Influence of basin-scale physical variables on life history characteristics of Cutthroat Trout in Yellowstone Lake. North American Journal of Fisheries Management 17:1046-1064.

Gresswell, R. E., and J. D. Varley. 1988. Effects of a century of human influence on the Cutthroat Trout of Yellowstone Lake. Pages 45-52 in R. E. Gresswell, editor. Status and management of interior stocks of Cutthroat Trout. American Fisheries Society, Symposium 4, Bethesda, Maryland.
Henderson, R., J. L. Kershner, and C. A. Toline. 2000. Timing and location of spawning by nonnative wild Rainbow Trout and native Cutthroat Trout in the South Fork Snake River, Idaho, with implications for hybridization. North American Journal of Fisheries Management 20:584-596.

Hogen, D. M., and D. L. Scarnecchia. 2006. Distinct fluvial and adfluvial migration patterns of relict charr, Salvelinus confluentus, stock in a mountainous watershed, Idaho, USA. Ecology of Freshwater Fish 15:376-387.

Homel, K. M., R. E. Gresswell, and J. L. Kershner. 2015. Life history diversity of Snake River finespotted Cutthroat Trout: managing for persistence in a rapidly changing environment. North American Journal of Fisheries Management 35:789-801.

Jones, R. D., D. G. Carty, R. E. Gresswell, K. A. Gunther, L. D. Lentsch, and J. Mohrman. 1985. Fishery and aquatic management program in Yellowstone National Park. U.S. Fish and Wildlife Service, Technical Report 1984, Yellowstone National Park, Wyoming.

Jordan, D. S. 1891. A reconnaissance of the streams and lakes of the Yellowstone National Park. U.S. Fish Commission Bulletin 9:41-63.

Kaeding, L. R. 2010. Relative contributions of climate variation, Lake Trout predation, and other factors to the decline of Yellowstone Lake Cutthroat Trout during the three recent decades. Doctoral dissertation. Montana State University, Bozeman.

Kaeding, L. R., and G. D. Boltz. 2001. Spatial and temporal relations between fluvial and allacustrine Yellowstone Cutthroat Trout, Oncorhynchus clarki bouvieri, spawning in the Yellowstone River, outlet stream of Yellowstone Lake. Environmental Biology of Fishes 61:395-406.

Kaeding, L. R., and T. M. Koel. 2011. Age, growth, maturity, and fecundity of Yellowstone Lake Cutthroat Trout. Northwest Science 85:431-444.

Koel, T. M., J. L. Arnold, P. E. Bigelow, C. R. Detjens, P. D. Doepke, B. D. Ertel, and M. E. Ruhl. 2015. Native fish conservation program, Yellowstone fisheries \& aquatic sciences 2012-2014, Yellowstone National Park. National Park Service, Yellowstone Center for Resources, YCR-2015-01, Yellowstone National Park, Wyoming

Koel, T. M., P. E. Bigelow, P. D. Doepke, B. D. Ertel, and D. L. Mahony. 2005. Nonnative Lake Trout result in Yellowstone Cutthroat Trout decline and impacts to bears and anglers. Fisheries 30(11):10-19.

Koel, T. M., D. L. Mahony, K. L. Kinnan, C. Rasmussen, C. J. Hudson, S. Murcia, and B. L. Kerans. 2006. Myxobolus cerebralis in native Cutthroat Trout of the Yellowstone Lake Ecosystem. Journal of Aquatic Animal Health 18:157-175.

Kruse, C. G., W. A. Hubert, and F. J. Rahel. 1997. Using otoliths and scales to describe age and growth of Yellowstone Cutthroat Trout in a high-elevation stream system, Wyoming. Northwest Science 71:30-38.

Kruse, C. G., W. A. Hubert, and F. J. Rahel. 2000. Status of Yellowstone Cutthroat Trout in Wyoming waters. North American Journal of Fisheries Management 20:693-705.

Liebelt, J. E. 1968. A serological study of Cutthroat Trout (Salmo clarkii) from tributaries and the outlet of Yellowstone Lake. Master's thesis. Montana State University, Bozeman.

McCleave, J. D. 1967. Homing and orientation of Cutthroat Trout (Salmo clarki) in Yellowstone Lake, with special reference to olfaction and vision. Journal of the Fisheries Research Board of Canada 24:2011-2044.

Meka, J. M., E. E. Knudsen, D. C. Douglas, and R. B. Benter. 2003. Variable migratory patterns of different adult Rainbow Trout life history types in a southwest Alaska watershed. Transactions of the American Fisheries Society 132:717-732.

Moore, J. W., M. McClure, L. A. Rogers, and D. E. Schindler. 2010. Synchronization and portfolio performance of threatened salmon. Conservation Letters 3:340-348.

Morita, K., S. Yamamoto, and N. Hoshino. 2000. Extreme life history change of White-spotted Char (Salvelinus leucomaenis) after damming. Canadian Journal of Fisheries and Aquatic Sciences 57:1300-1306.

Muhlfeld, C. C., T. E. McMahon, D. Belcer, and J. L. Kershner. 2009. Spatial and temporal spawning dynamics of native Westslope Cutthroat Trout 
(Oncorhynchus clarkii lewisi), introduced Rainbow Trout (O. mykiss), and their hybrids. Canadian Journal of Fisheries and Aquatic Sciences 66:1153-1168.

Nelson, M. L., T. E. McMahon, and R. F. Thurow. 2002. Decline of the migratory form in bull charr, Salvelinus confluentus, and implications for conservation. Environmental Biology of Fishes 64:321-332.

Northcote, T. G. 1992. Migration and residency in stream salmonids some ecological considerations and evolutionary consequences. Nordic Journal of Freshwater Research 67:5-17.

Northcote, T. G. 1997. Potamodromy in Salmonidae-living and moving in the fast lane. North American Journal of Fisheries Management 17:1029 1045.

Prince, A., and C. Powell. 2000. Clove oil as an anesthetic for invasive field procedures on adult Rainbow Trout. North American Journal of Fisheries Management 20:1029-1032.

Reinhart, D. P., and D. J. Mattson. 1990. Bear use of Cutthroat Trout spawning streams in Yellowstone National Park. Pages 343-350 in L. M. Darling and W. R. Archibald, editors. International conference on bear research and management, volume 8. International Association for Bear Research and Management, Victoria, British Columbia.

Ross, M. J., and C. F. Kleiner. 1982. Shielded-needle technique for surgically implanting radio-frequency transmitters in fish. Progressive Fish-Culturist 44:41-43.

Ruzycki, J. R., D. A. Beauchamp, and D. L. Yule. 2003. Effects of introduced Lake Trout on native Cutthroat Trout in Yellowstone Lake. Ecological Applications 10:23-37.
Sanderson, T. B., and W. A. Hubert. 2009. Movements by adult Cutthroat Trout in a lotic system: implications for watershed-scale management. Fisheries Management and Ecology 16:329-336.

Schrank, A. J., and R. J. Rahel. 2004. Movement patterns in inland Cutthroat Trout (Oncorhynchus clarki utah): management and conservation implications. Canadian Journal of Fisheries and Aquatic Sciences 61:1528-1537.

Thurow, R. F., C. E. Corsi, and R. K. Moore. 1988. Status, ecology, and management of Yellowstone Cutthroat Trout in the upper Snake River drainage, Idaho. Pages 25-36 in R. E. Gresswell, editor. Status and management of interior stocks of Cutthroat Trout. American Fisheries Society, Symposium 4, Bethesda, Maryland.

Varley, J. D., and R. E. Gresswell. 1988. Ecology, status, and management of Yellowstone Cutthroat Trout. Pages 13-24 in American Fisheries Society, Symposium 4, Bethesda, Maryland.

Varley, J. D., and P. Schullery. 1998. Yellowstone fishes: ecology, history, and angling in the Park. Stackpole Books, Mechanicsburg, Pennsylvania.

Warren, C. E., and W. J. Liss. 1980. Adaptation and aquatic environments. Pages 15-40 in R. T. Lackey and L. Nielsen, editors. Fisheries management. Blackwell Scientific Publications, Oxford, UK.

Watry, C. B., and D. L. Scarrnecchia. 2008. Adfluvial and fluvial life history variations and migratory patterns of a relict charr, Salvelinus confluentus, stock in west-central Idaho, USA. Ecology of Freshwater Fish 17:231-243.

Zale, A. V., C. Brooke, and W. C. Fraser. 2005. Effects of surgically implanted transmitter weights on growth and swimming stamina of small adult Westslope Cutthroat Trout. North American Journal of Fisheries Management 134:653-660. 